\title{
Increasing Women's Representation in France and
}

\author{
India
}

Dr. Gill Allwood

Dept. of Modern Languages

Nottingham Trent University

Clifton Lane

Nottingham NG11 8NS

gill.allwood@ntu.ac.uk
Dr Khursheed Wadia

Centre for Research in Ethnic Relations

University of Warwick

Coventry CV4 7AL

Khursheed.Wadia@warwick.ac.uk 


\section{$\underline{\text { Abstract }}$}

Cet article présente la question de la représentation politique des femmes en France et en Inde. Tout d'abord, il vise à mettre en évidence comment la représentation des femmes était inscrite à l'agenda politique de chaque pays. Ensuite, il propose un examen critique des arguments utilisés pour justifier la demande d'une meilleure représentation ainsi que de ceux pour s'y opposer. Enfin, il considère les conclusions que l'on peut tirer de ces deux cas. Dépassant les cadres comparatifs traditionnels utilisés par les féministes occidentales et en contestant l'insistance française sur l'idée d'une France unique, cet article identifie les particularismes et les points communs de chaque cas, pour tenter d'atteindre à ce que Shirin Rai appelle "un dépassement enraciné des frontières culturelles, historiques et politiques.” (Rai, 2000: 15).

This article explores the issue of women's political representation in France and India. Its aim is threefold. First, it explains how women's representation was placed on the political agenda. Second, it examines the arguments used to justify and oppose demands for better representation. Finally, it considers what conclusions can be drawn from the two cases. By moving beyond conventional comparative categories in Western feminist literature and beyond the isolationist insistence within France on its own specificity, the paper identifies the particularisms and commonalities of each case, thus attempting to achieve what Shirin Rai calls a "rooted crossing of cultural, historical and political boundaries." (Rai, 2000: 15). 


\section{Increasing Women's Representation in France and India*}

The immediate post-World War II period saw women gain equal political rights in a number of countries, amongst them France and India. Political participation research began to consider women's involvement in politics. However, because it focused on state institutions and political parties as the most important sites of political participation and because the presence of women within these sites was insignificant, the conclusions drawn were either that women were uninterested in and/or uninformed about politics or that their interest and knowledge derived from the male head of household. Moreover, when women's political participation was considered, the preferred location of study was the Western liberal democratic nation-state (Duverger, 1955; Dogan, 1955).

Only in the late 1970s and early 1980s, following a decade of women's grassroots activism, the growth of women's organizations and the development of women's studies, did the focus of participation studies move from elected bodies and political parties to non-conventional sites of politics, thus broadening the definition of political participation.

There emerged in the 1980s a body of feminist literature on women and politics which challenged traditional political science methods and explanations of women's absence from conventional politics. This literature wrote women into accounts of political participation in party and state institutions. While it substantiated the finding that the higher one scaled the pyramid of political power, the more limited women's presence became, it linked women's absence from political institutions with their subordinate position in society and with society's expectation that women's primary role was in the

\footnotetext{
* The authors thank the British Academy for financial assistance; participants at the Women's World Congress 2002 (Uganda, July 2002) for helpful feedback; Professor Danièle Joly and an anonymous reviewer for comments on early drafts.
} 
private sphere of home and family rather than in the public domain of politics and paid work (for example, Abzug and Kelber, 1984; Elshtain, 1981; Lovenduski, 1981).

It is notable that the absence of women from political power seems unconnected with voting behaviour. While the gender gap in electoral participation had almost disappeared in most Western democracies by the 1980s, this is not matched in other forms of participation (Randall, 1987: 50).

This literature also drew attention to women's political activism in social movements and community organizations (for example, Gelb Klein, 1983; Lovenduski and Hills, 1981; Randall, 1982). During the 1980s, comparative feminist political science identified cross-national/state commonalities and differences in women's movements, political participation and representation.

However, this literature on women's activism and movements focused on the nation-states of the industrialized North (for example, Dahlerup, 1986; Katzenstein and Mueller, 1987; Lovenduski and Hills, 1987; Norris, 1987), producing gendered models of oppression, participation and rights predicated on the experiences of Western women. By the 1990s, such comparative research came under criticism in the developing South because: "It ignores women's movements in the postcolonial world, considers women's movements [as] products of modernization or development, and assumes a sameness in the forms of women's oppression and women's movements cross-nationally" (Basu, 1995: 1). ${ }^{1}$ Scholars such as Chandra Mohanty accused Western, middle-class feminism of exclusively emphasizing gender (1991). Thus, postcolonial feminists (for example, Basu, 1995; Mohanty, 1991 and 1994; Spivak, 1994) have argued for a broader conception of gender, focusing on intersections and connections with class, race, 
ethnicity, religion and other identities, since women have never constituted a homogeneous community in any given territory. Nevertheless, within a framework of intensifying globalization, issues of equal rights, representation, political strategy and activism can and do cut across state borders, and this raises the necessity for feminist politics of making connections across differences.

The 1990s produced a vast feminist comparative politics literature on women's rights, political behaviour and participation which sought to expand research categories and to recognize and understand differences and similarities between women's participation and representation in the industrialized North and the developing South (for example, Mohanty et al., 1991; Nelson and Chowdhury, 1994; Rai and Livesley, 1996). Moreover, there is growing recognition, despite problems posed by comparative research in this field (Beckwith, 2000), that models of participation and best practice can be transferred as usefully from South to North as North to South.

It is in the light of the expanding literature on women, women's movements and political participation in the developing world and the challenges it poses to comparative feminist research that this paper compares two countries vastly different in terms of geography, economic development, society and culture. First, it examines the way in which women's representation was brought onto the political agenda. Second, it explores arguments used to justify the demand for better representation and counter-arguments used to oppose it. Finally, it asks what conclusions can be drawn from these two cases. The materials for analysis include parliamentary reports and debates, political speeches, party manifestos, press articles, academic and activist writings, conference proceedings and debates in the media between intellectuals, activists and politicians. Statistics were 
obtained from international databases, in particular those of the Inter-Parliamentary Union (IPU) and the United Nations Development Programme (UNDP). In the French case, information was drawn from participant observation at parity meetings, held at the Maison des Femmes in Paris, in 1998 and 1999. It is important to note that an article of this length cannot undertake an extensive comparison of women's political participation at all levels and its links with labour force participation, education and civil society organizations. Discussion is therefore limited to debates around increasing women's presence in political elites in the post-1945 period. The interested reader should refer to the relevant literature (for example, Allwood and Wadia, 2000; Menon, 2001; Nelson and Chowdhury, 1994) for a fuller understanding of the historical and political contexts in which these debates are situated.

\section{Why this comparison?}

Most cross-national participation studies concentrate on countries with similar histories, cultures, socio-economic and political characteristics. Few have compared developing countries with those of the West, ${ }^{2}$ but there are several reasons why this is useful.

First, the assumption that models constructed within the framework and experience of Western liberal democracies are applicable to developing countries must be and has been challenged. Models of gender oppression, participation and representation developed in liberal and earlier feminist theory have mostly flowed from North to South and West to East. These models have been exclusively gender-based until recently and are applied with difficulty to women in the developing world where connections with identities other than gender are more strongly emphasized in feminist literature. Hence, 
women's movements, feminist academics and agents in the West can learn useful lessons from the continuous negotiation between identities that is carried out by women in the developing world. Second, over the last two decades questions of gender equality, women's participation and empowerment have assumed critical relevance within the framework of governance and development. Women constitute a crucial reference group since, in terms of socio-economic, political and cultural resources, they are disadvantaged everywhere compared with men and particularly so in the developing world. If real development is about widening choices, opportunity and equality, then an analysis of the situation and progress of some of the world's most disadvantaged women can be instructive in formulating strategies of advancement and in assessing the successes and failures of such strategies. Third, the twentieth century has seen the internationalization of social struggles, including that for gender equality on the one hand, and of systems and instruments of oppression on the other hand. As this process unfolds, it becomes increasingly important to consider women's (and other) issues and struggles in a global context.

\section{Why France and India}

While France and India do not provide archetypes of industrialized and developing states, there are striking similarities, in two such different countries, between the discourse of those demanding increased women's representation and those opposed to it. These parallels run counter to a widespread idea in France of its own exceptionalism. Our paper explores the question of whether there might be some common threads in the 
opposition to women's political presence and whether feminist strategy could draw any lessons from these examples.

Both countries are secular, liberal democracies, although their political cultures have evolved according to their different histories; the most obvious example of difference being the fact that one was a colonial power, the other an ex-colony. In India, gender and the question of women's position in society became, in the words of Samita Sen, the "touchstone of the colonial-nationalist encounter" (2000: 6). While the British rulers accused Indian society of backwardness in the way it treated women and presented the protection of Indian women as part of their "civilizing" and modernizing mission, Indian nationalists counterposed their own vision of modernity by encouraging women to engage in political activity against the colonizers and calling for universal suffrage. Thus gender became the site of competing ideologies and visions of modernity. In France, by the end of the Second World War, voting rights for women became inevitable following the innumerable parliamentary debates of the inter-war period (Reynolds, 1996) and formed part of France's postwar modernization project.

There are nevertheless a number of parallels to be found in how the issue of women's representation developed in the two countries. Women in both India and France won the vote after the Second World War, ${ }^{3}$ following their important contribution to the Nationalist and Resistance movements respectively; their labour force participation and voting increased, although their presence within political elites did not. ${ }^{4}$

In both countries the question of women's under-representation in politics formed an important part of the political agenda in the late 1980s and 1990s, when the legitimacy of democratic institutions was being threatened by wide-scale political corruption and by 
the rise of anti-democratic and fundamentalist movements. Both countries introduced measures to increase women's presence in elected assemblies, and constitutional amendment bills were debated in their respective parliaments in the 1980s and 1990s, when the issue of women's equality was introduced within the framework of good governance rather than of social and economic disadvantage. While the question of women's political presence has been raised and measures to increase this presence have been taken in other countries during the last two decades, France and India have at various times been presented as cases of special interest to scholars of comparative politics.

France's apparent political uniqueness among Western liberal democratic states has been a subject of debate since the 1950s. Not surprisingly, the theme of "exceptionalism" was exploited in the 1990s by campaigners of the French parity ${ }^{5}$ movement, who emphasized France's exceptional status in terms of the underrepresentation of women in politics. France remains near the bottom of the EU league table and in sixty-sixth position in the IPU world league table of women's representation, but comes tenth in the UNDP's Gender-Related Development Index (GDI) for human development (IPU, 2002; UNDP, 2001). Women currently comprise 11.6 per cent of the combined membership of both houses of parliament in France (IPU, 2002). So, while France is not unique in terms of women's political representation, its interest lies in the immense gap between its world positions on women's representation and on other gender-related progress indicators. ${ }^{6}$

India, with its billion-strong population, is labelled the world's largest liberal democracy. It offers a vast scope for the theoretical and empirical examination of 
women's issues. Indian women constitute one-sixth of the world's female population. Furthermore, Indian society, its political institutions, processes and discourses are marked by more divisions than in nearly all other liberal democracies, so understanding gender issues is practically impossible without considering connections with caste, class, religion and regionalism.

Where women's under-representation is concerned, it is in these two countries that some of the most controversial political debates have taken place.

\section{The emergence and development of the issue of women's representation globally}

Women's representation arrived on the international political and feminist agendas in the late 1970s to early 1980s. Between 1985 and 1995, a series of UN conferences on women identified specific targets and a timetable for reaching them. In particular, the Beijing Platform for Action declared that women should occupy at least 30 per cent of political decision-making positions (Karam, 2000: 17). In addition, numerous international conferences and meetings were held on women and political participation. They assembled women parliamentary, government and civil society representatives and focused on strategies for increasing women's representation in political institutions at all levels, recognizing that this was inseparable from questions of women's poverty, employment and the removal of barriers to economic independence.

The issue of women's political representation was also established on the European agenda during the early 1990s, and equality between men and women in decision making was one of the six objectives of the Fourth Programme of Action of the European Commission (1996-2000). 
The collapse of East European communist regimes and the wave of democratization around the world provoked a growing critique of the shortfalls of liberal democracy in achieving real—as opposed to formal—gender equality. Women inside and outside political institutions continued to fight for measures to increase their presence in formal politics, and a growing comparative literature documents these struggles. Women's movements that in the 1970s and early 1980s had remained aloof from formal institutions (national and international) began to engage with them by the late 1980s.

This can be explained by the following factors. First, the 1980s saw the return of right-wing government and of neoliberal, anti-women's-rights policies in many leading economies (USA, Britain, Germany), thus producing a backlash against feminist movements and reducing their impact. Second, some countries experienced the institutionalization of feminism and the co-option of women's rights issues by the state. This had a disabling effect. Third, and in part due to the first two factors, women's movements in many countries became engulfed in internal conflicts, contributing to their demobilization. Fourth, in many developing and ex-communist European countries which had not experienced Western-type second-wave movements in the 1960s and 1970s but which were experiencing a combination of first and second-wave type movements in the 1980s, feminists were more inclined to build alliances within state institutions and to use international organizations to counter mainstream development views and strategies which they felt further impoverished women in the Third World and Eastern Europe. Thus, the weakening of women's movements in industrialized countries and the (re)emergence of women's movements in the developing world meant that 1980s feminists became more willing to engage with the state and to create international links to 
gain strength and continue making a positive difference in women's lives.

While feminists were readier to engage with national and international institutions, there was an awareness of the tensions among international agencies over the question of women's rights and control over a global economic agenda (influenced most notably by the USA through the World Bank and the International Monetary Fund) which placed often severe budgetary restrictions on national governments. These tensions are themselves often reflected in the international women's movement, especially between Western and Third World feminists or between liberal and radical or socialist feminists.

Governments in the 1980s and 1990s have used expressions of commitment to women's progress (through UN human rights instruments such as the Convention on the Elimination of all Forms of Discrimination against Women, International Labour Organization conventions and UN conferences) as a way to appear as beacons of "modernization" internationally, to (re)gain democratic credentials or to bow to intense pressure applied by women's movements.

\section{Women's representation on the Indian political agenda}

The question of equitable representation for disadvantaged groups has been at the heart of Indian political debate since Independence. The 1950 Constitution contained provisions to counter and eventually erase the damaging effects of the caste system. While some clauses outlawed discrimination on the grounds of caste, others included the notion of positive rights involving state implementation of what are sometimes referred to as affirmative action policies. Untouchables ${ }^{7}$ were given quotas in parliament, state assemblies, public sector posts and educational institutions. 
In 1979, the Backward Classes Commission, under B. P. Mandal, found that while backward castes ${ }^{8}$ constituted 52 per cent of the population, they were massively under-represented in state institutions. In its 1980 report, the Commission proposed wideranging discrimination measures in their favour. However, it was largely ignored until August 1990, when Prime Minister V. P. Singh decided to implement its recommendations. This decision led to intense debate and conflict, shaking Indian society and the political establishment to its very core and leading eventually to the downfall of the government. The debate revolved around the wisdom and justice of preferential politics.

The question of preferential politics and more specifically quotas for women in state representative institutions was seized upon by the party-based section of the 1990s Indian women's movement. Until then, women had not demanded reserved seats, either because entering mainstream political institutions was not a primary goal or because they wanted to do so on merit. Women had a long history of political struggle, fighting for the right to vote from the early part of the twentieth century, but they did not act only as women; they were also involved in the struggle for independence. Following waves of feminism in the 1920 s to 1930 s and in the late 1960 s to early 1970 s, ${ }^{9}$ a third wave of autonomous ${ }^{10}$ women's activism and popular struggle emerged in the late 1970s to early 1980s. This marked a phase of self-conscious commitment to feminist politics and through the 1980s, the movement addressed issues of equal rights and sexual harassment in the workplace, reproductive health, sexuality, alternative lifestyles and violence. On many of these issues, campaigns which began locally coalesced at the national level, giving the movement a new cohesiveness. 
This wave of feminist engagement began to ebb in the 1990s due to three interrelated factors. The first was co-option by the state of feminist issues. Secondly, state and international funding transformed under-resourced, autonomous groups (forming the motor of the movement in the 1970s and 1980s) into relatively well-off nongovernmental organizations (NGOs), and in the 1990s, discourses of development replaced those of struggle. Third, there emerged a common platform of women's sections of national political parties which collaborated on specific issues. Thus the contemporary women's movement seems more fragmented than that which emerged in the late 1970s. A network of party-based, professional and independent groups addressed issues of work, health, environment, civil and political rights (including the campaign for gender quotas in elected assemblies). It is the movement's party-based section that has been most vocal in favouring the reservation of seats for women, arguing that in order to empower women, women's movements must enter the political arena not only to redefine that space but also to engage in the brokering of power which takes place in political institutions. However, some sections of the movement have opposed gender quotas, and the debate has centred on competing claims to speak on behalf of women. ${ }^{11}$

\section{The history of initiatives and debate over reserved seats for women}

This issue was not new to 1990s India. A proposal to reserve seats for women was presented to the Constituent Assembly of 1946 but rejected, with many women members arguing that it was enough that the new constitution (which came into effect on June 26, 1950) provided for equality and universal suffrage and that positive discrimination would undermine women's achievements through merit. The question did not re-emerge until 
the 1970s when the Committee on the Status of Women noted that the numbers of women representatives in elected assemblies had not increased since $1952 .{ }^{12}$ In fact, the proportion of women in the Lok Sabha (Lower House) had declined from 4.4 per cent in the 1952-1957 assembly to 4.2 per cent in 1967-1971 (Sen, 2000: 49). The committee's report of 1974 recommended the reservation of seats at the municipal level; measures to include women in panchayats (units of local government); the adoption by political parties of minimum quotas for women candidates for all elections; and the establishment of all-women panchayats directly elected by village women. However, as these were only recommendations, their application by panchayats and political parties was either uneven or non-existent, and no recommendations were made for reservations at the state or national level.

In the 1980s and early 1990s a small number of states (including Karnataka, Kerala and Maharashtra) introduced their own laws on gender quotas. The success of these initiatives prompted the Seventy-Third and Seventy-Fourth Constitutional Amendment Acts to be passed in 1993, reserving one-third of all seats in panchayats and municipal councils for women. The impact of these acts was substantial. First, within three years, more than 350,000 women entered local government (Sen, 2000: 48). Second, the nature of issues on panchayat agendas changed, with women representatives acting across party lines to prioritize education, health and the provision of essential services like water and fuel (Jain, 1996: 5). Third, while the Seventy-Third and SeventyFourth Constitutional Amendment Acts were relatively uncontroversial, male opposition to gender quotas at higher levels hardened after 1993, marking the beginning of a sustained backlash. 
The Eighty-First Amendment Bill, introduced in September 1996 to reserve onethird of seats in the Lok Sabha and state legislatures, provoked intense opposition despite the fact that all main parliamentary parties (Congress, Janata Dal, BJP- Bharatiya Janata Party) and the two communist parties (CPI—Communist Party of India and CPI(M) Communist Party of India (Marxist)) had committed themselves to the principle of a onethird quota for women. Moreover, while the Common Minimum Programme of the then United Front (UF) government ${ }^{13}$ provided for a one-third quota in parliament and government, many UF MPs threatened to defy the government whip and filibuster the bill. The UF government was clearly unprepared for such opposition, as laws protecting women's rights had rarely before been subject to these levels of hostility. Amid the parliamentary conflict the bill was referred to a joint committee of the Lok Sabha and Rajya Sabha (upper house). However, it eventually lapsed with the dissolution of parliament. After 1996, the Constitutional Amendment Bill on reserved seats for women was reintroduced in each new session until 1999 but failed to pass. It was then referred to the Indian Electoral Commission which, in early 2002, published a formula on gender quotas, and Prime Minister Vajpayee agreed to convene an all-party meeting to discuss this formula. Not only have the bills encountered fierce parliamentary opposition, they have also caused cleavages within the women's movement. Until the 1970s, women's groups opposed quotas. During the 1970s, there were concerns about co-option by the state, and arguments about class and caste elitism continue to influence views on gender quotas. Feminists' distrust of the state was fuelled in the 1980s and 1990s when some of their central issues (in particular dowry deaths ${ }^{14}$ and rape) were co-opted by the state, which introduced seemingly radical yet ineffective legislation (Kumar, 2001). The 
reservations debates have brought about unexpected alliances inside and outside

parliament_-between, for example, liberal and Marxist feminists, and between women on the fundamentalist Right and parties on the Left. These debates will be discussed after a brief presentation of the way in which women's representation arrived on the French political agenda.

\section{Women's representation on the French political agenda}

Defining women's under-representation in political institutions as a political issue raises many questions about the nature of representation and citizenship in a political culture which attaches great importance to the concept of the abstract universal citizen. In French Republican thought, "le peuple" (the people as a single body) is sovereign. ${ }^{15}$ It is "le peuple" which elects its parliamentary representatives, who in turn represent the common will or the interest of the nation. Parliamentary representatives do not represent their own constituency and are not accountable to its members. Instead, holding a parliamentary mandate, they make decisions in what they determine to be the best interest of the nation. "Le peuple" is made up of individual citizens who are not conceived of as physically embodied human beings of a certain sex, class, race, ethnicity, age, physical ability or any other markers of social difference and identity. Such differences exist, but are seen as irrelevant to public life. "The citizen" is thus an abstract concept, equal in its sameness to all other citizens.

In recent years, and particularly since the bicentenary of the Revolution in 1989, feminists have engaged critically with key republican constructs, arguing that the apparently gender-neutral abstract citizen is in fact masculine; that the association of 
universalism with sameness or the absence of difference was not inevitable at the time of the Revolution; and that the notion of equality despite multiple differences could have developed instead (for example, Fraisse, 1997; Pisier and Varikas, 1997; Viennot, 1996). The consequences of the refusal to recognize the impact of differences means that discrimination and oppression resulting from these differences can neither be admitted nor addressed. The counter-model which induces fear in French Republicans is a peculiarly French construction of "communitarianism," perceived as American, in which politics is dominated by the representation of, and conflicts between, minorities (Amar, 1999).

The idea of an elected body reflecting the social composition of its electorate does not fit with the French conception of representation in which representatives' social origins are of no relevance to their decisions. This context posed problems in formulating a justification for quotas and explains why the successful amendment to an electoral bill limiting the number of candidates of a single sex to 80 per cent was overthrown by the Constitutional Council in 1982 (Loschak, 1983).

From the late 1970s and throughout the 1980s various attempts were made to increase women's representation. Since gaining political rights, women's representation in parliament had barely increased. Feminists argued that women did not lack will but rather were excluded from political office by a combination of historical, institutional and cultural practices (Allwood and Wadia, 2000: 132-56). Demands were made for quotas within party hierarchies and on candidate lists. By the 1990s, the efforts of campaigners and the opportunism of politicians made the media-friendly notion of "parity" a subject for public debate. ${ }^{16}$ In contrast to quotas, frequently associated with an outdated 
feminism, parity is supported by a broad spectrum of politicians, all main parties, European organizations, some feminists and intellectuals and public opinion. The competitive climate created by the cohabitation (1997-2002) of a left-wing prime minister and a right-wing president engendered a battle for the title of "political modernizer," and both supported a Constitutional Reform Bill resulting in an amendment to the Constitution, in June 1999, to introduce the following statements: "[T]he law favours the equal access of women and men to political office" and "The parties favour the equal access of women and men to electoral mandates and appointed posts." In 2000, an electoral law was passed, referred to as "the parity law," which introduced measures necessary to achieve parity in list elections. The first elections held under these new rules were the municipal elections of 2001. The new legal provisions had no effect on the 2002 presidential elections; for the 2002 legislative elections, the provisions offered financial incentives to parties to select more women candidates, but did not require the achievement of parity.

Campaigners side-stepped opposition to quotas by presenting parity as a new idea. They claimed they were not demanding proportional representation for the female part of the population or electorate, but rather equal participation in decision making for the two halves of humanity (Agacinski, 1999). That public opinion and a male-dominated political elite could accept this argument is not surprising. That many feminists accepted it is more so and demonstrates the recent swing towards a differentialist position within French feminism which, despite its international image, was in the 1970s and 1980s dominated by social constructionists.

In the 1970s, the women's movement, with its origins in the far Left, was 
uninterested in entering mainstream institutions, although it did engage with the state, notably in demanding legal abortions. By the 1990s feminists in France as elsewhere recognized the importance of including women in decision making and supported equal participation. But there were debates around strategy and theoretical underpinning. ${ }^{17} \mathrm{~A}$ vociferous minority of feminists expressed concern about excluding other groups from this claim to representation (Hirata et al, 1994), and this question has continued to divide feminists, politicians and intellectuals.

\section{Debates around women's representation in France and India}

Demands from women for representation in elected bodies, moves by politicians to achieve this, and pressure from international and regional quarters have provoked intense debate in both countries. The main themes of these debates can be organized under three main headings: democracy, equality and representation. ${ }^{18}$

\section{Democracy}

Participants in the debate over women's representation in both France and India have related democracy to two issues: discrimination and corruption. First, the principle of quotas or reservations is considered undemocratic because they constitute a form of (positive) discrimination and because one group is favoured at the expense of another. In France, opposition came mainly from the Right, in particular members of the upper house (the Senate) who claimed that if women candidates were imposed on them, this would infringe their right to choose freely. This ignores the fact that candidate "choice" is already restricted through party selection procedures.

In India, opposition to gender quotas on the grounds that this is undemocratic 
exists across party political and ideological lines although the most vociferous opponents are men. It has been argued that the Reservations Bill was undemocratic (and unconstitutional) as it violated article 325 of the Constitution: "No person is to be ineligible for inclusion in ... [the] electoral roll on the grounds of religion, race, caste or sex." Proponents of reservation counter this by also referring to the Constitution (Article 15(3)) which allows for special provisions on the grounds of sex if this furthers equality goals. Besides, they maintain that reserving seats for women simply follows positive discrimination measures already established for certain SCs/STs .

Second, the theme of democracy has been linked with the issue of corruption. In France, the parity campaign emerged at a time of growing concern about the "crisis of democracy." Evidence of this crisis was said to lie in the gap between the political elite and the electorate. Revelations of financial scandals in the 1980s and 1990s implicating significant numbers of politicians reinforced public opinion that legislators were interested only in personal gain, not democratic government. A widely held view that women politicians have more understanding of people's lives (clearly ignoring class) supported the argument that parity would solve the crisis of democracy. One of the slogans of the parity campaign was "[A] democracy that excludes half of the population is not a democracy": parity would make an imperfect democracy truly democratic.

In India, many supporters of reserved seats, mainly women, have advanced the notion that the probity of the Indian parliament would be enhanced if women entered it in greater numbers. However, opponents have plenty of evidence that women are not immune to corruption, especially at the national level where promises of pecuniary gain are made by big business lobbies. In addition, the issue of nepotism as a corrupt practice 
has figured large in the debate and it has been argued that gender quotas would lead to the establishment of a "bivi [wife] brigade" as male politicians fix up female relatives to contest reserved parliamentary seats.

Opponents of reserved seats argue that not only is this practice anti-democratic because it could lead to nepotism, but it works against merit-based entry. However, some proponents of reserved seats have tried to defend nepotism, arguing that family-based patronage networks constitute the foundation of Indian politics; women should use the family as an entry point, and then use their power to transform institutions of oppression including the family. The meaning of democracy is manipulated by both supporters and opponents, as is the meaning of representation and equality.

\section{Equality}

In both France and India, equality between the sexes is enshrined in the respective constitutions, but does not exist in practice. The definition of equality is fundamental, since the equal right to stand for election has failed in both countries to produce anything approaching equality of outcome. The enduring question is whether it is justifiable to introduce unequal measures in order to produce an equal outcome.

In France, equality has been associated with sameness, or the exclusion from public life of all markers of difference. Universalist discourse has also framed large parts of feminist thought, making the idea of equality in difference unacceptable and producing divisions between universalist feminists, who sought access for women to the abstract universal (that is, a future in which gender was irrelevant in every respect), and differentialist feminists, who wanted the feminine recognized and valued. This reemerged in the debate around parity in the 1990s. 
The term "parity" suggests numerical equality and this is what the campaign, launched in 1992, set out to achieve. This simple objective was less easy to distort than "equality," which can mean equality of opportunity (the equal right to stand for election), equality of outcome (the equal presence of men and women in parliament) or, more radically, an equal share of decision-making power. Despite the efforts of the main campaigners, however, it came to assume a multitude of meanings as the debates progressed. It was the justification behind the call for an equal presence which caused greatest conflict amongst feminists: Should women be present in parliament because they have been unjustly excluded but can do the job just as well as men, or should they be present because they have different interests, a different way of doing politics and are closer to the people than are men? In other words, is parity demanded on the grounds of sameness or difference?

In India too, the idea of equality has driven the campaign for reservations. Historically, the struggle for women's rights (including voting rights) was fought on the basis of women's traditional role in the home. Thus, women's equal presence in politics was seen as desirable because women brought with them unique skills. It was argued that their nurturing skills could be used in welfare politics and peace making, that their ability to administer household budgets could be adapted to public financial management and that their moral superiority would benefit public life generally. Some proponents of quotas, particularly male politicians, have readily used the idea that "feminine qualities" contribute to society's well-being; this argument is deemed not to upset gender relations and is therefore more saleable to their parties and constituents. However, to argue that women should be equally present in politics because of their differences from men is 
risky because the acceptance of difference can strengthen assertions that women are biologically unsuited to the bellicosity of political life. Both Indian and French feminists have had to tread carefully through the "equal but different" and "unequal measures for equal outcomes" arguments.

\section{$\underline{\text { Representation }}$}

Representation has been the key issue in debates over quotas. It can be argued that demands for gender quotas are based on the assumption that the equitable representation of women's interests can only be guaranteed by the presence of women, as men are unable or unwilling to represent them.

The French parity campaign assumed that only identity as women matters and can be represented without interference from race or class. Attempting to maintain the broadest possible appeal for the idea of parity, the main campaigners argued against encouraging other excluded groups demanding political representation. They did this by re-naturalizing sexual difference, making it different from all other (socially constructed) differences. This was quite an intellectual feat, especially when it was argued that escaping one's race is easier than escaping one's sex. It was claimed that women do not constitute a social category calling for representation in the sense of a sociological reflection of the electorate. Parity campaigners argued that such a representation would be wrong, since it would threaten the nation's unity, breaking it down into identity-based communities. Instead, they argued that humanity is universally dual, that both sexes reproduce society and that they should therefore govern it together. This argument was fiercely contested by some feminists, horrified to see years of struggle to denaturalize 
sexual difference undone so quickly and with so much legitimacy, but it was accepted by the political establishment and used by the former French prime minister Lionel Jospin to garner support for the Constitutional Amendment Bill. Universalism and its resistance to the representation of minorities has therefore survived the debates and ensuing legislation, by accommodating "duality" and abandoning claims to gender neutrality.

In India, the debate over who can legitimately represent a sociologically diverse electorate has been heavily marked by the issue of caste. The Constitutional Amendment Bill on gender quotas attracted intense opposition from politicians representing SCs/STs who rejected the bill as meaningless since women are not a homogeneous group. They accused the bill's supporters of being drawn into upper-caste male conspiracies aimed at reducing the presence of SCs/STs in the Lok Sabha in favour of women from upper castes. Thus, their acceptance of the bill was conditional on the establishment of a 27 per cent subquota for women from backward castes; if backward-caste men could not represent backward-caste women fairly, then neither could upper-caste women. Constitutional emphasis on positive rights for backward castes compared with a weaker framing of women's rights has allowed identities based on caste and community to gain primacy over sexual equality and to be used by those who fear loss of power. The fact that caste and community are also divided by class and gender and the principle that the individual rather than collectivity is the bearer of fundamental constitutional rights is easily dismissed. The Reservations Bill has been left pending over the last four years because its supporters have lost the arguments on representation in a climate created by the BJP government in which the protection of minority cultures has worked against women's representation. 
High-profile multiculturalism in India contrasts with the rejection of multiple identities in France. In France, opposition to quotas has been based on a perceived threat to national unity by claims from "other minorities." In India, however, arguments about protecting minority cultures and rights have been exploited by politicians and intellectuals in order to scupper the Reservations Bill. This has been helped not only by constitutional ambiguities but also by the BJP government's attempts to dismantle secular collectivities and to replace them with identity-based collectivities through which the citizen-state relationship can be mediated.

\section{Conclusion}

This study shows that some arguments used to oppose women's representation are common to both countries. Analyzing these arguments enables us to understand the obstacles to better representation and to devise strategies to overcome them.

First, the main conclusion to be drawn is that when demands for women's representation coincide with similar demands from other groups, a dilemma arises: Should one pursue exclusively the goal of women's representation or recognize other claims also but, in so doing, risk allowing women's representation to drop down the list of demands? For example, in the 2002 French legislative elections, the first national elections conducted under the new parity legislation, the urgency of uniting against the extreme right was perceived to override the commitment to increasing women's representation (Le Monde, 15 May 2002). [need more comprehensive reference: author's name, article name, page number if possible]

Left-wing feminists, in both India and France, have for years faced the dilemma 
of whether to advocate women's representation (and risk being accused of supporting a bourgeois demand) or to uphold class solidarity but relinquish women-specific demands. Indian feminists within the SCs/STs are also accused of making demands for women's representation at the expense of caste solidarity, and of supporting upper-caste women candidates to oust SC/ST men from their constituencies.

Second, it is justifiably argued that the demand for parity or quotas is not revolutionary and its acknowledgement is unlikely to impact extensively on women's lives. However, we can conclude from this study that it is a goal worth pursuing. It has been shown to have an impact on the numbers of women present in decision-making sites and evidence exists that women in politics bring different issues to the political agenda. In addition, it may contribute to the creation of a distinct political collectivity through which women's demands are articulated, without interference from traditionally oppressive institutions of public life and family. The struggle for women's representation in political institutions is important but it must form part of a wider strategy to improve the lives of all women. At the same time, questions of how to represent a heterogeneous population in conditions of social justice and of how to bring about meaningful citizenship for both sexes must be considered. Hence, the struggle for women's representation must not be isolated from other struggles.

\section{End Notes}

\footnotetext{
${ }^{1}$ Reference to feminist research in the South includes scholars working in the North but originally from the South.

${ }^{2}$ Exceptions include Hoskyns and Rai (1998); conference on "Re-negotiating the Politics of the Public and the PrivateGender and Politics in China and the Nordic Countries" (Shanghai, November 2002).
} 
${ }^{3}$ French and Indian women gained full voting rights in 1944 and 1950 respectively.

${ }^{4}$ Increased labour market participation cannot be considered a measure of women's "emancipation." Women predominate in part-time/short-term, low-paid jobs. Increased female employment has not changed the amount of time women spend on domestic labour. Thus, women lack two crucial resources necessary for high levels of political participation: sufficient income and time.

${ }^{5}$ Parity refers to numerical equality between the sexes in all state decision-making bodies, especially elected assemblies.

${ }^{6}$ Even then France's position is close to the USA and Italy. See IPU (2002); UNDP (2001).

7 "Untouchables" ("Scheduled Castes" in the Constitution) are those suffering discrimination and loss of opportunities due to their low status within the Hindu caste system.

${ }^{8}$ The term "backward," describing certain castes and classes, appears in the Constitution to refer to groups oppressed historically on grounds of gender, socio-economic position, culture and religion and who require legal protection and/or compensatory treatment. Three groups are identified: Scheduled Castes (SCs), Scheduled Tribes (STs) and Backward Classes (BC). "Scheduled Castes" are "untouchables." "Scheduled Tribes" are culturally isolated groups. SCs/STs enjoy quotas in numerous elected bodies and preferential policies relating to them are protective and/or developmental. "Backward Classes" refers to peoples with restricted or threatened rights. Article 15(4) includes women among "Backward Classes" since they suffer social and educational disadvantages.

${ }^{9}$ Studies of India's women's movements include: Desai (1997); Liddle and Joshi (1986); Menon (2001); Ray and Basu (1999); Swarup et al. (1994).

${ }^{10}$ Independent of parties and trade unions.

${ }^{11}$ For arguments within the debate see: Dhanda (2000); Kishwar (1997); Nath (1996a, 1996b); Rai and Sharma (2000); Ray (2000).

${ }^{12}$ Women's representation was discussed briefly in 1957, when Panchayat Raj (units of local government) structures were established and it was decided to co-opt women to cover the welfare of women and children at panchayat level. Only two states applied this rule: Maharashtra (1961) and West Bengal (1973).

${ }^{13}$ A coalition of centre-left parties, formed in the early 1990s, to oppose the Congress party and the rightwing Hindu BJP. 
${ }^{14}$ Murders of newly married women, usually committed by in-laws, for not continuing dowry payments after marriage.

${ }^{15}$ For an introduction to debates on women's representation see Millard and Ortiz (1998). In English, see Hunt (1996 ) and Scott (1996).

${ }^{16}$ Parity literature in French is vast. In English, see Allwood and Wadia (2000), chapters 8 and 9; Scott (1997).

${ }^{17}$ See special issues of Nouvelles Questions Féministes (1994; 1995) and Projets Féministes (1996).

${ }^{18}$ See also Sen (2000).

\section{References}

Abzug, Bella and Mim Kelber. 1984. Gender Gap. Boston: Houghton Mifflin Co. Agacinski, Sylviane. 1999. "Contre l'effacement des sexes." Le Monde, February 6, 1.

Allwood, Gill and Khursheed Wadia. 2000. Women and Politics in France: 1958-2000. London and New York: Routledge.

Amar, Micheline, ed. 1999. Le Piège de la parité: arguments pour un débat. Paris: Hachette.

Basu, Amrita, ed. 1995. The Challenge of Local Feminisms: Women's Movements in Global Perspective. Boulder: Westview.

Beckwith, Karen. 2000. "Beyond Compare? Women's Movements in Comparative Perspective." European Journal of Political Research 37: 431-68.

Chowdhury, Najma and Barbara Nelson. 1994. "Redefining Politics: Patterns of Women's Political Engagement from a Global Perspective." In Women and Politics Worldwide, ed. Barbara Nelson and Najma Chowdhury. New Haven and London: Yale University Press. 
Dahlerup, Drude, ed. 1986. The New Women's Movement: Feminism and Political Power in Europe and the USA. Thousand Oaks: Sage.

Desai, Manisha. 1997. "Reflections from Contemporary Women’s Movements in India." In Feminism and the New Democracy: Resiting the Political, ed. Jodi Dean. London, Thousand Oaks, New Delhi: Sage.

Dhanda, Meena. 2000. "Representation for Women: Should Feminists Support Quotas?" Economic and Political Weekly 3,33: 2969-76.

Dogan, Matteï. 1955. "L’Origine sociale du personnel parlementaire français élu en 1951." In Partis politiques et les classes sociales, ed. Maurice Duverger. Paris: Armand Colin.

Duverger, Maurice. 1955. The Political Role of Women. Paris: UNESCO.

Elshtain, Jean. 1981. Public Man, Private Woman: Women in Social and Political Thought. Oxford: Princeton University Press.

Fraisse, Geneviève. 1997. "La Démocratie exclusive: un paradigme français." Pouvoirs 82: 5-16.

Hirata, Helena, Danièle Kergoat, Michèle Riot-Sarcey and Eleni Varikas. 1994. "Parité ou mixité." Politis: la revue 6: 117-18.

Hoskyns, Catherine and Shirin Rai. 1998. "Gender, Class and Representation: India and the European Union." European Journal of Women's Studies 5, 3-4: 345-65.

Hunt, Lynn. 1996. The French Revolution and Human Rights: a Brief Documentary History. Boston and New York: Bedford Books of St. Martin’s Press.

Inter-Parliamentary Union. 2002. Women in National Parliaments: World Classification. Cited at http://www.ipu.org/wmn-e/classif.htm (April 11 and June 25, 2002). [Does this 
refer to the last date the web page was accessed? You should cite both the publication date of the article, as well as the last date you checked the Web site. The latter date should be as close as possible to when your article appears in the Journal, for example (Article published April 11, 2002; Web site last accessed November 26, 2003)] Jain, Devaki. 1996. "Panchayati Raj: Women Changing Governance." In Gender in Development Monograph Series. New York: UNDP.

Karam, Azza. 2000. "Beijing + 5: Women's Political Participation: Review of Strategies and Trends." In Women's Political Participation and Good Governance: $21^{\text {st }}$ Century Challenges. New York: UNDP.

Katzenstein, Mary and Carol Mueller, ed. 1987. The Women's Movements of the United States and Western Europe. Philadelphia: Temple University Press.

Kishwar, Madhu. 1997. "Women's Marginal Role in Politics." Manushi 97. Cited at http://freespeech.org/manushi/97/politics.html (February 26, 2002).[see above comment]

Kumar, Radha. 2001. "From Chipko to Sati: the Contemporary Indian Women's Movement." In Gender and Politics in India, ed. Nivedita Menon. New Delhi: Oxford University Press.

Liddle, Joanna and Rama Joshi. 1986. Daughters of Independence: Gender, Caste and Class in India. London: Zed Books.

Loschak, Danièle. 1983. "Les Hommes politiques, les 'sages' (?)... et les femmes (à propos de la décision du Conseil Constitutionnel du 18 novembre 1982)." Droit Social 2: $131-7$.

Lovenduski, Joni. 1981. "Toward the Emasculation of Political Science." In Men's Studies Modified, ed. Dale Spender. London: Pergamon Press. 
Lovenduski, Joni and Jill Hills, eds. 1981. The Politics of the Second Electorate: Women and Public Participation. London: Routledge and Kegan Paul.

Menon, Nivedita, ed. 2001. Gender and Politics in India. New Delhi: Oxford University Press.

Millard, Eric and Laure Ortiz. 1998. "Parité et représentations politiques." In La Parité: enjeux et mise en oeuvre, ed. Jacqueline Martin. Toulouse: Presses Universitaires du Mirail.

Mohanty, Chandra. 1991. "Cartographies of Struggle: Third World Women and the Politics of Feminism." In Third World Women and the Politics of Feminism, eds. Chandra Mohanty, Ann Russo and Lourdes Torres. Bloomington, Indiana: Indiana University Press.

Mohanty, Chandra. 1994. "Under Western Eyes: Feminist Scholarship and Colonial Discourses." In Colonial Discourse and Post-Colonial Theory: A Reader, eds. Patrick Williams and Laura Chrisman. New York: Columbia University Press.

Mohanty, Chandra, Ann Russo and Lourdes Torres, eds. 1994. Third World Women and the Politics of Feminism. Bloomington, Indiana: Indiana University Press.

Nath, Meenakshi. 1996a. "Cutting Across Party Lines: Women Members of Parliament Explain their Stand on Reservation Quotas." Manushi 96. Cited at http://free.freespeech.org/manushi/96/intvus.html ( March 21, 2002). [please see earlier comments]

Nath, Meenakshi. 1996b. "And the One who Differs ...." Manushi 96. Cited at http://free.freespeech.org/manushi/96/intvus.html (March 21, 2002). [see earlier comments] 
Nelson, Barbara and Najma Chowdhury, eds. 1994. Women and Politics Worldwide. New Haven/London: Yale.

Nouvelles Questions Féministes. 1994. "La Parité 'pour'." Special issue, 15/4.

Nouvelles Questions Féministes. 1995. "La Parité 'contre'." Special issue, 16/2.

Norris, Pippa. 1987. Politics and Sexual Equality the Comparative Position of Women in Western Democracies. Brighton: Wheatsheaf.

Pisier, Evelyne and Eleni Varikas. 1997. "Femmes, république et démocratie: l’autre dans la paire?" Pouvoirs 82: 127-43.

Projets Féministes. 1996. "Actualité de la parité." Special issue: 4-5.

Rai, Shirin, ed. 2000. International Perspectives on Gender and Democratisation. Basingstoke: Macmillan.

Rai, Shirin and Geraldine Livesley, eds. 1996. Women and the State: an International Perspective. London: Taylor and Francis.

Rai, Shirin and Kumud Sharma. 2000. "Democratising the Indian Parliament: the Reservation for Women Debate." In International Perspectives on Gender and Democratisation, ed. Shirin Rai. Basingstoke: Macmillan.

Randall, Vicky. 1982. Women and Politics. Basingstoke: Macmillan.

Randall, Vicky. 1987. Women and Politics. $2^{\text {nd }}$ edition, Basingstoke: Macmillan.

Ray, Bharti and Aparna Basu, eds. 1999. From Independence towards Freedom: Indian Women since 1947. New Delhi: Oxford University Press.

Ray, Sumita. 2000. "The Women's Reservation Bill of India: a Political Movement Towards Equality for Women." Temple International and Comparative Law Journal 13, 3: 53-72. 
Scott, Joan Wallach. 1996. Only Paradoxes to Offer: French Feminists and the Rights of Man. Cambridge, Massachusetts and London: Harvard University Press.

Scott, Joan Wallach. 1997. "'La querelle des femmes' in the Late Twentieth Century." New Left Review 1, 226: 3-19.

Sen, Samita. 2000. Towards a Feminist Politics? The Indian Women's Movement in Historical Perspective. Cited at http://ww.worldbank.org/gender/prr (February 26, 2002).[see earlier comments]

Spivak, Gayatri. 1994. "Can the Subaltern Speak?" In Colonial Discourse and PostColonial Theory: A Reader, ed. Patrick Williams and Laura Chrisman. New York: Columbia University Press.

Swarup, Hem Lata, Niroj Sinha, Chitra Ghosh and Pam Rajput. 1994. "Women’s Political Engagement in India: Some Critical Issues." In Women and Politics Worldwide, ed. Barbara Nelson and Najma Chowdhury. New Haven and London: Yale University Press.

United Nations Development Programme (UNDP). 2001. Human Development Report 2001. Cited at http://www.undp.org/hdr2001/indicator/ (April 11, 2002).[see earlier comments]

Viennot, Eliane, ed. 1996. "La Démocratie à la française" ou les femmes indésirables. Paris: L’Université de Paris VII. 
